\title{
Classification of Barriers to Implementing the Car-Sharing System: Case study for Tehran
}

\author{
Siamak Ahmadian', Grzegorz Sierpiński ${ }^{2, *}$ \\ ${ }^{1}$ Iran Construction Engineering Organization \\ Sari - North ring way - Nezam Mohandesi Street, Mazandaran, IRAN \\ siamack_ahmadian@yahoo.com \\ ${ }^{2}$ Silesian University of Technology, Faculty of Transport and Aviation Engineering, Department of Transport Systems, \\ Traffic Engineering and Logistics \\ Krasińskiego Str. 8, 40-019 Katowice, POLAND \\ * Corresponding Author: grzegorz.sierpinski@polsl.pl
}

\section{Extended Abstract}

In recent years, car-sharing systems have been announced as a way to increase mobility and to decrease the number of single-occupant vehicles, congestion, and air pollution in many parts of the world [1]. Car sharing can significantly help reducing traffic congestion, fuel consumptions and $\mathrm{CO} 2$ emissions; hence, improving fuel economy and the air pollution problems. Therefore, the application of shared vehicles could be considered as a viable strategy that can potentially improve mobility in terms of environmental benefits, as follows: Producing less air pollution as a result of the presence of fewer cars on the roads, increasing accessibility through sharing cars, improving urban land use and development and also being costeffective.

Based on the above information, it should be stated that only the correct implementation of the car-sharing system can change the face of the city. This study aims to identify existing problems for implementing car sharing system, especially in large cities with high traffic density and population. The identified problems were grouped and classified, which may accelerate the taking of corrective actions. Using such a pattern and identifying the required share of vehicles on the street, the study could minimise the amount of air pollution, costs, and traffic congestion.

As a case study area, capitol of Iran was chosen. Car sharing is a novel concept in the Iranian market. The transportation system of Tehran, with 9 million residents, size, and geographical characteristics, has many complexities. That transportation system in addition to 9 million residents, gives services to more than 1 million people who are commuting daily to Tehran from the suburbs [2]. Numbers reported by the World Health Organization show that four of the 10 worst-polluted cities in the world are in Iran. Car ownership in Iran has continued to increase in recent years - despite economic restrictions and the ongoing sanctions against the country. The problem for the country and more specifically the cities is that the current rate of urbanization is causing difficult to solve problems for municipalities, in terms of the number of vehicles on the streets. However, there is a growing trend to develop the public transportation in urban areas, whether it be subways, bus-rapidtransit systems, congestion zones and special coach lanes. There are several obstacles or problems for bringing car sharing system to Tehran. As examples may be listed firstly, that insurance premiums would be incrementally higher due to a greater chance of car damage as Tehran's urban structure, although improving, is somewhat outdated, forcing drivers to park their vehicles on the streets -- a difficult task in many areas. Another issue is that there is no precedent for this in the Iranian car insurance industry and many insurers would not accept fleet insurance with so many participating drivers. Also, many people in Tehran are too attached to their current comfortable commute. A further potential problem future investors could face, if they were to initiate a project like car-sharing, would be whether they would choose high-end vehicles, or they would focus on more low-end vehicles abundant in the market [3]. Detailed classification may help to understand the problems and start correction.

The results of this study would encourage public authorities, and the related legislators and government agencies to shift from personal transportation to shared mobility while creating a positive impact on the environment and society. 


\section{References}

[1] A. Edrissi, M. Askari, C. Smaniotto Costa, Electric-vehicle car-sharing in one-way car-sharing systems considering depreciation costs of vehicles and chargers, International Journal of Transportation Engineering, 2019.

[2] M. Mojtehedzadeh, Assessment of Urban Transport System in Tehran, Suti Assessment Report, 2019.

[3] https://financialtribune.com/articles/economy-business-and-markets/7501/car-sharing-in-tehran 